\title{
The opinions of hotel managers ahout halal hotel concept: A research in Cappadocia
}

\author{
Lütfi Buyruk*, Durmuş Ali Aydemir
}

\author{
Keywords: \\ Halal tourism, \\ Halal hotel, \\ Cappadocia.
}

\author{
Article History: \\ Submitted: 21.01.2021 \\ Revised: 30.04 .2021 \\ Revised: 22.09.2021 \\ Accepted: 25.09.2021 \\ Published Online: 25.09.2021
}

\begin{abstract}
The number of halal business hotel concept in Turkey in recent years, especially in regions where intensive maritime tourism has been increasing. However, there are no such hotels in the Cappadocia destination. The main purpose of this study is to determine the thoughts of hotel managers in the Cappadocia tourist region on halal tourism and the concept of halal hotels. Using the semi-structured interview technique, open-ended questions were asked by the researchers to the managers of 17 four and five-star hotels with tourism management certificates in the region. The obtained data were subjected to content analysis and interpreted. The main findings obtained from the research are that hotel managers in Cappadocia see "halal tourism" as a rapidly developing market in the world that will become even more important in the future, and there is no need for a halal hotel concept to promote the demand for the region; they did not intend to make arrangements in accordance with the halal hotel concept and obtain halal hotel certification in their businesses. They kept prayer rugs in their hotel upon the requests of the guests, they turned their meeting rooms into masjids when requested; and hotel rooms have a sign showing qibla on nightstand drawers.
\end{abstract}

\section{Doi: https://doi.org/10.31822/jomat.2022-7-1-31}

\section{Introduction}

Tourism is seen as the best way to reduce poverty, increase employment and create economic growth, especially in developing countries. For this reason, it is developing faster than other sectors (Tanrısever, Pamukçu, \& Batman 2016). Today, due to the increasing competition in the tourism sector and the similarity of the offered tourist products, businesses have to put forward different products and services from their competitors and find new markets (Arpacı, Uğurlu, \& Batman, 2015; Karakuş, 2019). At the same time, it can be an important strategy to consider the potential of different market segments, since the characteristics of tourists are not homogeneous (Okumus, Shi, \& Dedeoglu, 2021). The concept of halal tourism has emerged in recent years in line with the wishes and expectations of the guests and has begun to take place in the tourism literature as a research area. Especially in the last decade, the halal tourism market in the world is showing a development that cannot be ignored. Many investors from Muslim and non-Muslim countries who want to take part in the world halal tourism pie have started to be interested in the concept of halal tourism. It is foreseen by the authorities that Muslim tourists will spend $\$ 157$ billion in 2020 . According to some, this figure will reach $\$ 200$ billion (Hospitality News Middle East, 2018).

In recent years, tourism operators in many countries have shown interest in the concept of halal tourism. This interest in halal tourism may be due in part to the increase in the Muslim population worldwide (Battour \& Ismail, 2016). In fact, the Muslim population of the world which was 1.8 billion in 2015, is estimated to reach 2.2 billion in 2030 and 2.6 billion in 2050 (Nasdaqomx, 2012; Pewforum, 2017). Parallel to the increase in the Muslim population, efforts to provide products and services in line with the expectations of this population traveling for holiday purposes and thus

\footnotetext{
*Corresponding Author

Lütfi Buyruk: Assoc. Prof., Nevșehir Hacı Bektaș Veli University, Nevșehir, Turkey, Email: buyruk@nevsehir.edu.tr, Orcid Id: 0000-0002-1921-7782 i

Durmuş Ali Aydemir: $\quad$ Lecturer N., Nevşehir Hacı Bektaş Veli University, Nevşehir, Turkey, Email: durmusaliaydemir0@ gmail.com, Orcid Id: 0000-0003-1842-7021 (iD)
} 
trying to get more shares from the "halal tourism" pie can be considered as the reasons of this interest. Mastercard-Crescent Rating (2019) report that halal tourism is an impressive rapidly growing dynamic market segment. Muslim travel market is expected to reach US $\$ 220$ billion by 2020 and it is estimated that US $\$ 300$ billion will increase by $36 \%$ in the next six years.

The study primarily focuses on the concepts of halal, halal tourism and halal hotels. Then, description will be made about the development of the halal hotel business in Turkey. The field research is aimed at determining the opinions of hotel managers in Cappadocia region about halal tourism and halal hotel concept. The data obtained by the semi-structured interview method were analyzed and the results were evaluated.

On the other hand, this study was conducted with the belief that it would be possible to obtain the most realistic ideas about whether it would be appropriate to invest in a halal hotel concept in a destination from hotel managers working in that destination. Because they best observe the current demand for the destination and the future development course of the demand.

\section{Literature Review}

\section{Halal and Halal Tourism Concepts}

The life styles of Muslims are generally shaped by the orders and prohibitions of the Quran, the holy book of the Islamic religion, and the circumcision practices taken from the lifestyle and discourses of the Islamic prophet Hz. Muhammad (Tekin, 2014). As previously mentioned, the concept of halal tourism has emerged in recent years in line with the wishes and expectations of the guests and has begun to take place in the tourism literature as a research area. Halal is a word of Arabic origin and related to Islam which is not only involved to food products. Halal is a concept which includes various products and services offered to Muslims in the sense that they are religiously appropriate or permissible (Tuna, 2016; Samori, Salleh, \& Khalid, 2016: 132). The word "halal" in the Turkish Language Association's Current Turkish Dictionary (2019) is defined as "anti-haram which is not contrary to the rules of religion and is not prohibited in terms of religion". Although the concept of halal, which is emphasized with precision by Muslims, is identified with food, different products and services are also considered within halal measurements. The concept of halal includes cosmetic products, health products, bankfinance and tourism services as well as food (Çallı, 2014; Sulıgoj \& Marusko 2017; Nordin \& Rahman, 2018). Thus, the concept of halal is not only used to express the conformity of food and drink with Islamic principles, in a broader sense, it is a significant concept that has influence in all Muslim living spaces (Batman, 2017; Birinci \& Karakuş, 2020).

As of 2018, Turkey ranks 4th in most preferred halal tourism destinations in the world, following Malaysia, Indonesia and the United Arab Emirates. According to the visa requirements, air connection and transportation infrastructure scores, which are easy to access the destinations, Turkey has taken the first place among the most frequently visited 10 halal tourism destination. (Mastercard-Crescent Rating, 2018). Turkey is ranked 6 th in the rankings to have the most appropriate halal tourism services performed between Muslim countries. These rankings and scores are shown in table 1.

Table 1: Top 10 Muslim destinations offering the most affordable halal tourism services

\begin{tabular}{|l|l|l|l|l|l|l|}
\hline Destinations & Restaurant & $\begin{array}{l}\text { Places of } \\
\text { orship }\end{array}$ & Airport & $\begin{array}{l}\text { Unique } \\
\text { experiences }\end{array}$ & Hotel & Total points \\
\hline 1. Malaysia & 95.0 & 100.0 & 100.0 & 10.2 & 75.2 & 380.4 \\
\hline 2. Indonesia & 90.0 & 100.0 & 100.0 & 18.0 & 59.4 & 367.4 \\
\hline 3. Saudi Arabia & 95.0 & 100.0 & 100.0 & 9.2 & 62.9 & 367.1 \\
\hline 4. United Arab Emirates & 80.0 & 100.0 & 100.0 & 10.4 & 72.3 & 362.7 \\
\hline 5. Egypt & 85.0 & 100.0 & 80.0 & 53.8 & 37.9 & 356.7 \\
\hline 6. Turkey & 75.5 & 100.0 & 86.7 & 40.8 & 51.5 & 354.5 \\
\hline 7. Qatar & 90.0 & 100.0 & 100.0 & 9.6 & 54.6 & 354.2 \\
\hline 8. Oman & 80.0 & 100.0 & 100.0 & 9.6 & 46.5 & 336.1 \\
\hline 9. Bahrain & 70.0 & 100.0 & 100.0 & 20.8 & 44.8 & 335.6 \\
\hline 10. Iranian & 85.0 & 100.0 & 80.0 & 33.2 & 34.4 & 332.6 \\
\hline
\end{tabular}

Source: Mastercard\&Crescentrating Global Muslim Travel Index, 2018. 
Halal tourism, which has recently gained popularity and is rapidly becoming a new phenomenon in the tourism industry, refers to tourism products offered according to Islamic beliefs and practices (Nasdaqomx, 2012). In the past traditionally, halal tourism has been associated with pilgrimage and umrah travels. There has always been an interest in pilgrimage to Mecca, which is connected to the Islamic religious. However, the rise of wealthy middle-class Muslim consumers and their starting to see travel as part of everyday life has changed the choice of Muslims from traditional destinations such as Mecca to the best holiday destinations (Ryan, 2016; Nasdaqomx, 2012).

In the meantime, it is necessary to mention a conceptual issue that should not be underlined. There are differences between the term "Islamic tourism" in the Western literature and "halal tourism". Boğan and Sarışı (2018) emphasize that it is not appropriate to substitute Islamic tourism with halal tourism. Islamic tourism refers to Muslims' travels to Mecca on religious grounds to perform the pilgrimage and become a pilgrim. For religious purposes, it is possible to name the travels of people belonging to all religions as "religious tourism". Since early ages religious has been an important reason for traveling. Pilgrimage, which consists of religious travel to a temple or a holy place, is one of the oldest forms of tourism (Timothy \& Olsen, 2006; Tuna, 2016; Türker, 2016). Yet, halal tourism has nothing to do with worship. Halal tourism is a recreational tourism and people of the Islamic religious travel for the reasons why each person wants to travel. The main motivation is not religious and worship, and Muslims want to travel and see the world for reasons that motivate many tourists (Ryan, 2016; Tuna, 2016; Batman, 2017). The demand for halal tourism has increased as traveling Muslims want to travel without any worries about their religious beliefs. In addition, the increase in the Muslim population, the increase of the young Muslim population with a high level of education, the increasing knowledge of Muslims about halal products, the increase in the income level of Muslims are other reasons for the increased interest in halal tourism (Dilek \& Çakmak, 2017).

\section{Halal Hotel Concept}

In general, halal hotel management is similar to other traditional hotels. The most important difference is that the hotel is designed and operated in accordance with Islamic rules. In addition to the halal kitchen and restaurant where halal food and drinks are prepared and served; halal hotels should also be free from bars, discos where serving alcoholic beverages and any other entertainment that violates Islamic rules (Mahamood et al., 2018). The structure of halal hotel management is determined according to Islamic rules with a number of practices such as halal meals, places of worship, places without pork and alcohol, separate spa and sports facilities for men and women (Han et al., 2019). In this case, halal hotel can be defined as accommodation establishments, whose main function is to meet the needs of the guests overnight, designed according to Islamic rules and offering their guests the needs of food, drink, sports, rest and entertainment within the framework of halal principles.

Halal hotels are briefly defined as businesses that provide services to their customers in accordance with Islamic rules. However, when we look at the sector, the number of hotels offering all products and services in accordance with Islamic rules is limited. For this reason, hotels in the halal tourism industry are classified under 3 groups. Only hotels where alcohol consumption is prohibited, "nonalcoholic hotel" or "dry hotel" ;hotels offering halal food, rooms with Quran and prayer rugs, separating services for men and women "partially halal hotel" and in addition to those mentioned above, hotels that comply with Islamic rules for all services from hotel design to financing are called "halal hotels" (Akbaba \& Çavuşoğlu, 2017; Saad \& Ali, 2014).

Halal hotels are the ones that take into account their religious sensitivity and privacy in the services they offer to meet the accommodation needs of their guests (Samori et al. 2016). In order to qualify the hotel business as halal, they must have 3 main factors; (1) halal environment, (2) halal food and beverages, and (3) halal business finance. Today's hotels with these basic qualities position themselves as halal hotels and strive to attract Muslim guests (Bilgin \& Karakaş, 2017). Table 2 shows the basic features that must be present in halal hotels, which are different from traditional hotels.

\section{Halal Hotel Management in Turkey}

In the context of halal tourism, halal accommodation establishments and halal food establishments are the two main types of enterprises. Turkey is one of the first countries to implement the halal hotel concept. Especially in the coastal areas, the number of businesses applying this concept as a holiday hotel is gradually increasing. The concept of halal hotels is 
Table 2: Basic Qualifications of Halal Hotels

\begin{tabular}{|c|c|}
\hline Hotel Sections & Qualifications \\
\hline ROOMS & $\begin{array}{l}\text { Holy Quran, prayer rugs and prayer beads must be kept, Qibla must be specified in a fixed } \\
\text { place of the room. } \\
\text { If there is a television, recorded obscene channels and CDs, DVDs and tapes should not be } \\
\text { available. } \\
\text { - Pets should not be allowed in rooms. } \\
\text { - Alcoholic and cola acidic beverages in mini refrigerators in rooms, cleaning and cosmetic } \\
\text { products should not be kept in bathrooms and sinks without certificate. } \\
\text { Customers should be placed in their rooms in compliance with Islamic rules. Guests arriving } \\
\text { as a couple should be asked for a marriage certificate before giving the room. } \\
\text { Toilets should not be facing Qibla. Toilets must be equipped with appropriate bidet. }\end{array}$ \\
\hline FOOD \& BEVERAGE & $\begin{array}{l}\text { - Food and beverages provided to the hotel and all kinds of food must comply with halal food } \\
\text { conditions. } \\
\text { - Alcoholic beverages should not be served in all areas of the hotel. } \\
\text { - Music broadcasting should not be done in places such as restaurants, cafes and buffets. } \\
\text { There is no waste in Islam. The situations that cause wastage should be checked and } \\
\text { precautions should be taken and the guests should be informed. } \\
\text { During Ramadan, the property should be served in accordance with iftar-sahur times. } \\
\text { However, necessary precautions should be taken for children, patients and the elderly who } \\
\text { cannot fast. }\end{array}$ \\
\hline PUBLIC PLACES & $\begin{array}{l}\text { - The hotel should have a pool, masjid, beach, sports and entertainment areas which are } \\
\text { allocated for men and women. } \\
\text { Entertainment and animation activities must comply with Islamic rules. } \\
\text { - } \quad \text { Events should be organized according to prayer times. } \\
\text { - } \quad \text { Any kind of gambling should not be allowed inside the hotel. } \\
\text { Both guests and staff should wear non-low-cut Islamic clothing. }\end{array}$ \\
\hline
\end{tabular}

less common in the destinations located outside the coasts in Turkey (Tekin, 2014).

The year of 2002 can be considered as a milestone in the emergence of halal hotels in Turkey. While the number of halal concept hotel in Turkey until 2002 was only 5 , this number reached 44 by the year 2011; some sources state the number even more than 60 (Yllmaz \& Güler, 2017). It is quite difficult to identify clearly the number of halal hotels in Turkey. There is no statistical information on this subject. However, when you search halalbooking.com which is the first among the halal hotel search engines, there will be 1620 "halal" or "Muslim friendly" worldwide Reservation information is available for accommodation. When the countries where the company stays on the site selected tab Turkey, 591 enterprises are encountered. Among the qualifications of these hotels, when the "no-alcohol policy/whole property" tab is selected 414 enterprises are seen. Therefore, this figure indicates the number of accommodation which has "halal" concept in Turkey. Again according to the data on this site, there are 75 five-star halal hotels, 132 four-star halal hotels, 187 three-star halal hotels and 11 two-star halal hotels. The number of hotels with no star classification (unrated) and estimated to be municipal certified is 186 (Halalbooking, 2019).

In parallel with the developments in the world, the interest in halal tourism trend and halal tourism concept is increasing by hotel investors and hotel operators in some destinations in Turkey. In recent years, it has been seen that some hotel businesses, especially in the Alanya region, have rapidly transformed their concepts into halal hotels. However, these applications require some changes in the hotel infrastructure such as the construction of separate masjids, swimming pools, gymnasiums for men and women, and the creation of ambience reflecting Islamic values in interior design. Employees should also be trained on how to provide quality service to these vulnerable guests (Boğan \& Sarışık 2018). Therefore, implementing the halal hotel concept requires investments such as money and time. Before investing in a halal hotel, it is necessary to conduct a comprehensive research. Otherwise, the money, time and efforts spent may be wasted.

There are many studies dealing with the development of halal tourism in the world and the issue of Halal tourism conceptually (Timothy \& Olsen, 2006; Samori, Salleh, \& Khalid, 2016; Ryan, 2016; Battour \& Ismail, 2016). Some studies in the world and Turkey about the Halal concept of the hotel is also available (Carboni \& Janati 2016; Boğan \& Sarışık 2018; Mahamood et al., 2018; Nordin \& Rahman, 2018). However, there are very few studies investigating the thoughts of hotel managers on the halal hotel concept. 


\section{Methodology}

In the literature, there are some studies such as the perceptions of the halal hotel concept made by the owners of the house boarding-style accommodation business by the Carboni and Janati (2016), and examining the opinions of the hotel managers in Çanakkale on the concept of halal tourism (Diker et al., 2018). There is no study on this subject in Cappadocia region and this is the first study conducted for hotel managers in the region.

The main purpose of this study is to determine the opinions of hotel managers on the concept of halal tourism and halal hotels in the Cappadocia destination. The data were collected by using semistructured interview technique which is one of the qualitative research methods. As is known, interviewing is one of the techniques commonly used in social science research (Bradford \& Cullen, 2012) The main reason for this is that the interview is an effective method to obtain information about the individual's attitudes, emotions, thoughts and beliefs (Flick, 2009; Fylan, 2005). The semistructured interview technique used in this study, depending on the flow of the interview, the researcher may influence the flow of the interview with different side or sub-questions, and allow the person to open his / her answers and elaborate (Blandford, 2013; Adams, 2015). Because of these characteristics, semi-structured interview technique was preferred in the collection of research data.

\section{Population and Sample}

The population of the research consists of 4 and 5 star hotels located in Nevşehir which is the center of Cappadocia region. According to the data of the Provincial Directorate of Culture and Tourism, there are 22 hotels with four and five stars in Nevşehir were included in the research. Three thermal hotels in Kozakl district were excluded from the research and it was aimed to interview the managers of 19 four and five star hotels in Nevşehir Center and districts. However, for various reasons (not to make an appointment, not to accept the interview etc.), it was possible to contact the managers of 17 hotels. The interviewers serve as hotel manager, front office manager and reservation manager. The interviews were made by the authors in the hotels in 2019, and each interview lasted approximately 30 minutes.

In this research, purposeful sampling method was used to determine the sample. This method is used in qualitative research and includes the people who are directly related to the subject. Therefore, interviews with the managers of the hotels which are located in the research population and in accordance with the determined criteria of the research were analyzed.

\section{Data Collection Tool}

The questions to be asked in the interview were determined by using the literature. A total of 4 questions were asked to the interviewers face to face. These are (1) What do you think about the halal tourism market in the world? (2) Is there a need for a halal hotel concept in order to increase the tourist demand for Cappadocia? (3) Qibla signs, prayer rugs etc. are necessary in hotels to satisfy tourists from Muslim countries; are these applications available in your hotel? (4) Do you plan to make arrangements in accordance with the demand for halal hotels and get a halal hotel certificate for your hotel in the future? According to the flow of the interview, necessary explanations were made about the questions; by creating a sincere atmosphere, tried to get comfortable, honest and correct answers to the questions asked. The answers given to 4 questions by the interviewers were deemed sufficient for the information desired to be obtained.

The data obtained were analyzed by content analysis. Comparisons were made between the data and whether they were matched and overlapped. Findings were interpreted by tabulating with frequency analysis technique.

\section{Findings and Discussion}

A common feature of the 17 managers interviewed was that they worked as a hotel manager in the region for more than 10 years. Therefore, they have sufficient knowledge and experience in the structure of demand to the region and hotel management. Eight of the managers are hotel managers, six are front office managers and three are reservation managers.

Hotel Managers' Opinions on the World's Halal Tourism Market

The answers to the question of What do you think about the halal tourism market in the world? show that most of the managers describe this market as a "developing market". Again, managers emphasize that this market is "an important market" and "demand for the market will increase and will continue to develop". Answers to this question include "a bright future", "a market to be supported" and "an alternative market to the Western market” (Table 3). 
Table 3: Hotel Managers' Opinions on the World's Halal Tourism Market

\begin{tabular}{|l|l|l|l|}
\hline $\mathbf{R a n k}$ & Opinions about halal tourism market & $\mathbf{f}(*)$ & $\mathbf{\%}$ \\
\hline $\mathbf{1}$ & A developing market & 12 & 71 \\
\hline $\mathbf{2}$ & An important market & 8 & 47 \\
\hline $\mathbf{3}$ & Demand for the market will increase and continue to improve & 7 & 41 \\
\hline $\mathbf{4}$ & A bright market for the future & 5 & 29 \\
\hline $\mathbf{5}$ & A market that needs to be supported & 3 & 18 \\
\hline $\mathbf{6}$ & An alternative market to the Western market & 3 & 18 \\
\hline
\end{tabular}

(*) Some interviewees expressed more than one opinion.

Source: Authors

Hotel Managers' Opinions on the Need for a Halal Hotel Concept to Increase Tourist Demand for Cappadocia As a second question to the hotel managers interviewed, "is there a need for a halal hotel concept in order to increase the tourist demand for Cappadocia?" was asked. Among the answers received, "there is no need, the number of Muslim tourists coming to the region is few" took first place. The other answers are "there is no need at the moment, if the demand increases may be needed", "small supply can be created, not lack of region". Only 2 hotel managers replied: "Yes, a few halal hotels can be opened especially for the demand of domestic guests". Again, 2 hotel managers stated that they think as "if 1-2 halal hotels are opened the region would benefit" (Table 4).

Some answers to the question of whether a halal hotel concept is needed to increase the tourist demand for Cappadocia are as follows:

- "Halal hotel concept is not needed in the region. Demand from Muslim countries to the region does not exceed $10 \%$. Cappadocia destination attracts more tourists from Christian and other religions"

- "There is no need for a Halal hotel, the historical structure of the region, museums and historical sites do not attract the attention of tourists from Muslim countries."
- "If one or two halal hotels are opened, there will be a return to the region. However, let's open 3 halal hotels, the fourth does not work. Because demand is limited. '

Hotel Managers' Opinions on Qibla Signs, Prayer Rugs, etc. to Satisfy Tourists from Muslim Countries

When the question was asked to hotel managers "Qibla signs, prayer rugs etc. are necessary in hotels to satisfy tourists from Muslim countries; are these applications available in your hotel? they all said yes and stated that such applications are necessary. Almost all of them have said that some of these applications are included in their hotels according to the demands of Muslim tourists. Table 5 lists the answers to this question.

Table 5: Hotel Managers' Opinions on Qibla Signs, Prayer Rugs, etc. to Satisfy Tourists from Muslim Countries

\begin{tabular}{|l|l|l|l|}
\hline Rank & $\begin{array}{l}\text { Opinions on Qibla Signs, Prayer Rugs, etc. } \\
\text { to Satisfy Tourists from Muslim Countries }\end{array}$ & $\mathbf{f}(*)$ & $\mathbf{\%}$ \\
\hline $\mathbf{1}$ & Required, we have applications & 17 & 100 \\
\hline $\mathbf{2}$ & We have prayer rugs, we give on request & 17 & 100 \\
\hline $\mathbf{3}$ & $\begin{array}{l}\text { There are signs showing the Qibla in the } \\
\text { drawers of the nightstand }\end{array}$ & 15 & 88 \\
\hline $\mathbf{4}$ & We're removing alcohol from the mini bar & 8 & 47 \\
\hline $\mathbf{5}$ & We organize the meeting room as a masjid & 5 & 29 \\
\hline $\mathbf{6}$ & We have the Qur'an and give it on request & 3 & 18 \\
\hline
\end{tabular}

(*) Some interviewees expressed more than one opinion Source: Authors

Table 4: Hotel Managers' Opinions on the Need for a Halal Hotel Concept to Increase the Tourist Demand for Cappadocia

\begin{tabular}{|c|c|c|c|}
\hline Rank & $\begin{array}{l}\text { Opinions about whether a halal hotel concept is needed to increase the tourist } \\
\text { demand for Cappadocia }\end{array}$ & $\mathbf{f}(*)$ & $\%$ \\
\hline 1 & There is no need for a small number of Muslim tourists visiting the region & 14 & 82 \\
\hline 2 & No need for now, may be needed if demand increases & 8 & 47 \\
\hline 3 & Small supply can be created, not short of region & 5 & 29 \\
\hline 4 & Yes, several halal hotels can be opened for domestic guests & 2 & 12 \\
\hline 5 & If one or two halal hotels are opened, it will help the region. & 2 & 12 \\
\hline
\end{tabular}

(*) Some interviewees expressed more than one opinion.

Source: Authors 
When the answers are analyzed, it is seen that prayer rugs are kept in all hotels and given to guests when requested. Most hotels have a Qibla sign in their rooms. When requested, they remove alcoholic beverages from the minibar and turn the meeting room into a masjid. Only 3 hotel managers stated that they have a Koran in their hotel to be given to guests upon request.

\section{Hotel Manager's Opinions about making arrangements in accordance with the demand of Halal Hotel and receiving Halal Hotel Certificate in the future}

Finally, to the hotel managers, "Do you plan to make arrangements in accordance with the demand for halal hotels and get a halal hotel certificate in your hotel in the future?" was asked. In response to this question, all of the hotel managers stated that they did not see the need to obtain a halal hotel certificate in the future. A significant number of managers stated that they do not intend to make arrangements in accordance with the halal hotel concept in the future. Three managers said that they would consider making partial arrangements such as non-alcoholic restaurants and masjids, and two executives said they could make arrangements upon request (Table 6).

Table 6: Hotel Manager's Opinions about making arrangements in accordance with the demand of Halal Hotel and receiving Halal Hotel Certificate in the future

\begin{tabular}{|l|l|l|l|}
\hline Rank & $\begin{array}{l}\text { Opinions for making arrangements in } \\
\text { accordance with the demand of halal hotels } \\
\text { and obtaining halal hotel certificate in the } \\
\text { future }\end{array}$ & $\mathbf{f}(*)$ & $\%$ \\
\hline $\mathbf{1}$ & We do not need a Halal hotel certificate & 17 & 100 \\
\hline $\mathbf{2}$ & $\begin{array}{l}\text { We do not intend to arrange in accordance with } \\
\text { the concept of halal hotel in the future }\end{array}$ & 12 & 71 \\
\hline $\mathbf{3}$ & $\begin{array}{l}\text { Partial arrangement, such as non-alcoholic } \\
\text { restaurant and masjid }\end{array}$ & 3 & 18 \\
\hline $\mathbf{4}$ & Can be arranged upon request & 2 & 12 \\
\hline
\end{tabular}

Here are some answers to the question "Would you consider making arrangements in your hotel in accordance with the request for a halal hotel and getting a halal hotel certificate?":

- "We do not need halal hotel regulations and certificate when we look at the demand. The demand for Muslim tourists is around $5 \%$ in Cappadocia."

- "Not as long as there is demand from the West. We do not want to create a Halal hotel image and lose the Western market. We respectfully serve all religions."
- "You can think about Konya, it is convenient to destination structure. Not suitable for Cappadocia."

- "We are the biggest hotel in the region with 435 rooms. If there is sufficient demand in the future, we can consider arrangements in line with the halal hotel concept."

\section{Conclusion and Suggestions}

In this study conducted to investigate the opinions of hotel managers about halal tourism and halal hotel concept in Cappadocia touristic region, it was found that the majority of hotel managers in the region described the halal tourism market as a bright and important future in the world. Another finding of the study is that most of the hotel managers think that a halal hotel concept is not needed to increase the demand for tourists to Cappadocia from Muslim countries. Because according to the hotel managers, the number of tourists coming from Muslim countries does not exceed $10 \%$ in the current tourist profile of Cappadocia. However, in order to please the tourists from the Muslim countries and domestic conservative tourists, such as applications prayer rugs, the sign showing the Qibla, to remove alcoholic beverages from the mini bar and organize the meeting room as a masjid are available in almost all hotels. All of the hotel managers involved in the interview do not intend to receive a halal hotel certificate in the future. Again, a significant number of managers do not intend to implement the halal hotel concept in the future. The main reason for this is that tourists from the Western world and other non-Muslim countries compose the destination's market.

The results of this study are similar to the findings in the study (Diker et al., 2018) investigating the views of hotel managers in Halal tourism in Çanakkale. Hotel managers in Çanakkale have a negative perception about the concept of halal tourism as the demand for halal tourism is not sufficient in the province. As the demand for halal tourism is very low in the Cappadocia region, the hotel managers do not favor to halal hotel concept and get halal hotel certificate. In addition, these results, it should be kept in mind that halal hotel investments and applications should be made in accordance with the target markets of the destination. It would be meaningless to engage in halal hotel investment and management without the data on the current demand structure and the direction of the demand.

However, increasing demand of halal tourism is a phenomenon that will not be denied in Turkey and 
the World. In the 3rd Tourism Council gathered in Ankara (2017), the issue of halal tourism was also discussed. Market research for halal tourism, identification of promotion and marketing strategy; Gulf, Arab, African and Balkan countries and Turkish Republics as the target market is proposed. When we look at the Muslim tourists coming from abroad to the destination of Cappadocia, it is seen that they originated mostly from Malaysia, Indonesia, Gulf countries and Turkish Republics and a small amount of Singapore. Especially, Malaysia and Indonesia should be taken into consideration in promotion and marketing strategies as they are important halal tourism markets.

In the halal tourism, as in other tourism types, food and beverage services are also important besides accommodation. Therefore, in the promotional campaigns aimed at the Muslim tourist market, together with halal hotels, Turkish cuisine, in which preparing dishes using halal foods can be brought to the fore.

It is seen that some businesses use the halal tourism label to provide marketing advantage. Therefore, halal hotel criteria should be determined by the Ministry of Culture and Tourism. Hotels that do not provide the necessary infrastructure and standards should be prevented from using the halal hotel label in their sales and marketing activities.

Finally, considering the current market profile of the Cappadocia destination, it can be concluded that the concept of halal tourism and halal hotels is not necessarily encouraged; the opinions of hotel managers are also in this direction. There are already some hotels in the Kozakl district and districts such as Göreme and Uçhisar that serve according to Islamic principles in line with the beliefs of the hotel owners and the demands of the domestic market.

It is obvious that the halal tourism trend is developing gradually in the world and in Turkey. However, it is a fact that extensive research should be done before investing in a certain concept. This research will be beneficial for investors who plan to invest in halal hotels in the Cappadocia region.

Among the limitations of the research is that the real numbers of tourists coming to the Cappadocia region from Islamic countries could not be obtained. If these tourist numbers were obtained, it would support the thoughts of hotel managers. Not being able to interview more hotel managers can be counted among the limitations of the research.

Future research may explore the necessity of halal tourism investments in different destinations to guide investors and regional or national tourism policies. In addition, researches can be made on whether the investment will be appropriate for different tourism concepts for a destination.

\section{References}

Adams, W. C. (2015). Conducting semi-structured interviews, Handbook of Practical Program Evaluation, 4th ed., Newcomer, K.E., Hatry,H.P.\&Wholey,S.J. (edits), Jossey-Bass.

ADL Document and Consulting Services. (2019). Halal Hotel Certificate Rules. Retrieved from http://adlbelge.com/helal-otel-sertifikasi.

Akbaba, A., \& Çavuşoğlu, F. (2017). Helal otel kavramı ve Türkiye'de helal otel sertifikasyonu, International Journal of Contemporary Tourism Research 1, pp. 48-58.

Arpacı, Ö. , Uğurlu, K., \& Batman, O. (2015). Helal Konseptli Otel İşletmelerine Yönelik Yapılan Müşteri Şikâyetleri Üzerine Bir Araştırma, Bartın Ün. İBF Dergisi, Cilt 6, Sayı 11, (181198).

Batman, O. (2017). Sorularla Helâl Turizm / Helâl Turizm Nedir veya Ne Değildir?, 1.International Halal Tourism Congress / 07-09 April 2017 / Alanya / Turkey. Pp. 30-32.

Battour, M., \& Ismail, M. N. (2016). Halaltourism: Concepts, practises, challenges and future, Tourism Management Perspectives, 19, pp 150154.

Bilgin, Y., \& Karakaş, A. (2017). Otel İşletmelerinin Helal Niteliğinin Müşteri Değerlendirmelerine Yansımaları: İstanbul'daki Helal Konseptli Otel İşletmeleri Örneği, Uluslararası Yönetim Iktisat ve İsletme Dergisi, Cilt 13, Sayı 4, ss.911-926.

Birinci, C. M., \& Karakuş, Y. (2020). Halal Recreation and Reflections on the Hospitality Industry. In I. Yazıcıoğlu, Ö. Yayla, \& T. Çetin (Eds.), Tourism and Hospitality Studies. Bern, Switzerland: Peter Lang.

Blandford, A. (2013). Semi-structured qualitative studies, The Encyclopedia of Human-Computer Interaction, Soegaard, M. \& Dam, R. F. (eds.)., 2nd Ed. Aarhus, Denmark.

Boğan, E., \& Sarışık, M. (2018). Halal tourism: conceptual and practical challenges, Journal of Islamic Marketing.

Bradford, S., \& Cullen, F. (2012). Research and research methods for youth practitioners. London: Routledge 
Çallı, İ. D. (2014). Using Halal Concept in Ethnic Marketing "An Analysis on Food Commercials Broadcasted in Germany" Anadolu University Journal of Social Sciences, v.14, 4, 43-55.

Carboni, M., \& Janati, M. I. (2016). Halaltourism de facto: A casefrom Fez, Tourism Management Perspectives 19, 155-159.

Diker, O., Yıldırım, H. M., \& Tabatabaeinasab, M. (2018). Determining the Halal Tourism Concept Perceptions of Hotel Managers in Çanakkale, Turkish Studies, Volume 13/26, Fall.

Dilek, S., \& Çakmak, F. (2017). Helal turizm eğilimleri: kastamonu ilinde bir uygulama. Insan ve Toplum Bilimleri Araştırmaları Dergisi, 6(6), 314-339.

Flick, U. W. E. (2009). An introduction to qualitative research. London: SAGE Publishing.

Fylan, F. (2005). Semi-structured interviewing, A Handbook of Research Methods for Clinical and Health Psychology, Miles, J. \& Gilbert, P. (edits), Oxford University Press, New York.

GIMDES. (2019). How should a Halal hotel be? Retrieved from http://www.gimdes.org/helal-otel-nasilolmali-2.html\#more-4928) Retrieved 07.02.2019

Halalbooking.com (2019). Hotels in Turkey. Retrieved from https://tr.halalbooking.com/

Han, H., Al-Ansi, A., Olya, H. G. T., \& Kim, W. (2019). Exploring halal-friendly destination attributes in South Korea: Perceptions and behaviors of Muslim travelers toward a non-Muslim destination, Tourism Management 71, 151- 164.

Hospitality News Middle East. (2018). The global halal tourism sector is driven by millennials Retrieved from

http://www.hospitalitynewsmag.com/en/event/the -global-halal-tourism-sector-is-driven-bymillennials and muslim-travelers-are-expectedto-spend-usd-157-billion-by-2020/) Retrieved 06.02.2019

Karakuş, Y. (2019). Identifying the Best Alternative Tourism Product for a Destination: the case of Cappadocia. Revista Anais Brasileiros de Estudos Turísticos - ABET, 9 (1). https://doi.org/10.34019/22382925.2019.V9.16929

Mahamood, S. F., Fikri, A., \& Nor, N. S. N. M. (2018). Modelling Grand BlueWave Hotelin Managing Challenges of Islamic Hotel Performance (IHP): An Overview of the Islamic Spirituality Instilled, Proceedings of the 3rd International Halal Conference (INHAC 2016), Springer Nature Singapore PteLtd.,pp. 283-289.

Mastercard-Crescent Rating (2018). Mastercard \& Crescentrating Global Muslim Travel Index 2018. www.crescentrating.com) Retrieved: 07.02.2019
Mastercard-Crescent Rating. (2019). MastercardCrescent Rating Halal Travel Frontier 2019 Report. www.crescentrating.com, Retrieved: 07.02.2019

Nasdaqomx. (2012). The Global Halal Industry: An Overview, Edbiz-Nasdaq Omx Sharia Indexes.

Nordin, N. S. A., \& Rahman, F. A. (2018). A Critical Review of the Muslim-Friendly Hospitality Services Standard (MS 2610:2015) in Malaysia, Proceedings of the 3rd International Halal Conference (INHAC 2016), Springer Nature Singapore Pte Ltd., pp. 211-222.

Okumus, B., Shi, F., \& Dedeoglu, S. B. (2021). What is the Role of Demographics in Tourists' Attitudes Towards Foods? Journal of Gastronomy and Tourism, 5 (4), 207-220. https://doi.org/10.3727/216929721X16105303036 562

Pewforum. (2017). The Changing Global Religious Landscape, http://www.pewforum.org/ 2017/04/05/the-changing- global-religiouslandscape/\#global-population-projections-2015to-2060, Retrieved 08.02.2019.

Ryan, C. (2016). Halal Tourism, Tourism Management Perspectives 19, pp.121-123.

Saad, H. E., \& Ali, B. N. (2014). Sharia-compliant hotels in Egypt: Concept and challenges. Advances in Hospitality and Tourism Research (AHTR), 2(1), 1-15.

Samori, Z., Salleh, N. Z. M., \& Khalid, M. M. (2016). Current trends on Halal tourism: Cases on selected Asian countries, Tourism Management Perspectives 19, pp 131-136.

Sulıgoj, M., \& Marusko, H. (2017). Hotels and Halaloriented Product: What Do Hotel Managers in Slovenia Think?, Organizacija, Vol. 50, No.4, pp. 314-323.

Tanrısever, C., Pamukçu, H., \& Batman, O. (2016). New Tourism Trends In The World and Their Adaptations To Turkey, GÜSBEED, Gümüşhane Üniversitesi Sosyal Bilimler Enstitüsü Elektronik Dergisi, Cilt 7, Sayı 16, ss.55-72.

Tekin, Ö. A. (2014). İslami Turizm: Dünyadaki ve Türkiye'deki Genel Durum Üzerine Bir İnceleme. Journal of International Social Research, 7(29), ss.750-766

Timothy, D. J., \& Olsen, D. H. (2006). Tourism, religion and spiritual journeys. London: Routledge.

Tuna, F. (2016). The Role and Potential of Halal Tourism in Turkey, Alternative Tourism in Turkey, Egresi, I. (Ed.), GeoJournal Library 121, pp. 259- 267, Springer, Switzerland.

Türker, N. (2016). Religious Tourism in Turkey, Alternative Tourism in Turkey, Egresi, I. (Ed.), 
GeoJournal Library 121, pp.151-172, Springer, Switzerland.

Turkish Language Association. (2019). Current Turkish Dictionary. Retrieved from www.sozluk.gov.tr

Yılmaz, L., \& Güler, M. E. (2017). Türkiye'de Muhafazakâr Değerler Bağlaminda Turizm ve Tatil Algisındaki Değişme, International Journal of Contemporary Tourism Research 1, pp.17-25. 
2022, 7 (1): 31-40

https://doi.org/10.31822/jomat.2022-7-1-31

\title{
INFO PAGE \\ The opinions of hotel managers about halal hotel concept: A research in Cappadocia
}

\begin{abstract}
The number of halal business hotel concept in Turkey in recent years, especially in regions where intensive maritime tourism has been increasing. However, there are no such hotels in the Cappadocia destination. The main purpose of this study is to determine the thoughts of hotel managers in the Cappadocia tourist region on halal tourism and the concept of halal hotels. Using the semi-structured interview technique, open-ended questions were asked by the researchers to the managers of 17 four and five-star hotels with tourism management certificates in the region. The obtained data were subjected to content analysis and interpreted. The main findings obtained from the research are that hotel managers in Cappadocia see "halal tourism" as a rapidly developing market in the world that will become even more important in the future, and there is no need for a halal hotel concept to promote the demand for the region; they did not intend to make arrangements in accordance with the halal hotel concept and obtain halal hotel certification in their businesses. They kept prayer rugs in their hotel upon the requests of the guests, they turned their meeting rooms into masjids when requested; and hotel rooms have a sign showing qibla on nightstand drawers.
\end{abstract}

Keywords: Halal tourism, Halal hotel, Cappadocia.

\section{Authors}

Full Name Author contribution roles Contribution rate

Lütfi Buyruk: Methodology, Resources, Writing - Original Draft, Writing - Review \& Editing, Supervision, $70 \%$

Author statement: Author(s) declare(s) that All procedures performed in studies involving human participants were in accordance with the ethical standards of the institutional and/or national research committee and with the $1964 \mathrm{Helsinki}$ declaration and its later amendments or comparable ethical standards. Declaration of Conflicting Interests: The author(s) declared no potential conflicts of interest with respect to the research, authorship, and/or publication of this article

This paper does not required ethics committee report

Justification: This research was conducted before January 1, 2020. For this reason, it is exempt from "ULAKBIM TRDizin" criterion. 